\author{
Ks. Czesław Noworolnik* \\ UPJPII w Krakowie Wydział Teologiczny Sekcja w Tarnowie
}

\title{
NAUCZANIE O STWORZENIU OD SOBORU WATYKAŃSKIEGO II DO KATECHIZMU KOŚCIOLA KATOLICKIEGO
}

W pierwszym zdaniu naszego Credo wyznajemy: „Wierzę w Boga Ojca wszechmogącego, Stworzyciela nieba i ziemi”. Prawda ta jest podstawą dla zrozumienie całej rzeczywistości, w której żyjemy. Należy wobec powyższego zgodzić się z twierdzeniem M. Kehla, że „nasz świat - rozpatrywany w całości i we wszystkich szczegółowych aspektach - należy rozumieć w jego relacji do stwarzającego Boga, który daje mu istnienie i sens. Jest to podstawa, na której wspierają się wszystkie pozostałe wypowiedzi wiary o Bogu i świecie"1. Problematyka stworzenia była przez wieki stałym punktem zainteresowania naukowców i zwykłych ludzi. Tematyką tą z naukowego punktu widzenia zajmowali się teolodzy i przedstawiciele nauk empirycznych. Magisterium Kościoła wielokrotnie musiało prezentować swoje stanowisko wobec sporów pojawiających się na styku wiary i nauki w kwestiach dotyczących teorii pochodzenia świata i życia. Rozwój techniki i postęp $\mathrm{w}$ badaniach przyrodniczych dostarcza wciąż nowych danych empirycznych w tej dziedzinie, ale odkrywa także nowe problemy. Współczesna teologia staje wobec tego w obliczu konieczności udzielania odpowiedzi na ciągle pojawiające się pytania. Nawiązując do tego, Benedykt XVI postawił kwestię, która może stanowić inspirację dla poszukiwań teologicznych. W Katechezie z 6 lutego 2013 roku papież pytał, czy w epoce nauki i techniki można jeszcze mówić o stworzeniu? ${ }^{2}$. Okazuje się, że nie tylko można, ale

${ }^{*}$ Ks. Czesław Noworolnik, kapłan diecezji tarnowskiej, doktor teologii, wykładowca teologii dogmatycznej na Wydziale Teologicznym Sekcja w Tarnowie UPJPII w Krakowie; w latach 2000-2003 wykładowca teologii dogmatycznej w Salvatorian Institute of Theology and Philosophy w Morogoro (Tanzania); członek Zarządu Stowarzyszenia „Sinicum” im. Michała Boyma SJ działającego na rzecz pomocy Kościołowi w Chinach; autor cyklicznej audycji w radiu RDN Małopolska „Glosariusz Wiary”.

${ }^{1}$ M. Keh1, I widziat Bóg, że to jest dobre. Teologia stworzenia, Poznań 2008, s. 11.

2 Por. Benedykt XVI, Katecheza. Bóg, stwarzajac, ukazuje swa wszechmoc (6 lutego 2013), http://www.deon.pl/religia/kosciol-i-swiat/z-zycia-kosciola/art,13238, benedyktxvi-wierze-w-boga-stworzyciela-,strona,2.html (dostęp: 22.02.2013). 
wręcz należy w dzisiejszych czasach mówić o stworzeniu. Jan Paweł II podkreślał, że kwestie związane z prawdą o stworzeniu dotykają nie tylko problemu pochodzenia świata, ale także innych tajemnic ludzkiego istnienia: Kim jest człowiek? Jaki jest sens i cel życia ludzkiego? Co jest dobrem, a co złem? Czy i dlaczego cierpienie ma sens? ${ }^{3}$

Według Jana Paweł prawda o stworzeniu zawsze „odgrywała ogromną rolę $\mathrm{w}$ formacji duchowej, moralnej i kulturalnej" "4. W niniejszym tekście pragnę zwrócić uwagę na jeden $\mathrm{z}$ aspektów bogatej problematyki stworzenia. Temat określony przez organizatorów Sympozjum niejako z góry określił ramy czasowe poszukiwań. Chodzi o czas pomiędzy rokiem 1965, czyli datą zakończenia Soboru Watykańskiego II, a rokiem 1992 - a ściślej: pomiędzy 7 grudnia 1965 roku, kiedy to Paweł VI podpisał Konstytucję duszpasterską o Kościele w świecie współczesnym Gaudium et spes, a 11 października 1992 roku, kiedy to Jan Paweł II promulgował Katechizm Kościoła Katolickiego konstytucją apostolską Fidei depositum.

Problematyka artykułu została także ściśle sprecyzowana. Chodzi o ukazanie nauczanie o stworzeniu w tych ramach czasowych: „Nauczanie o stworzeniu od Soboru Watykańskiego II do Katechizmu Kościoła Katolickiego".

Kontekst, czyli miejsce i tematyka Sympozjum, podpowiada, o jakie nauczanie chodzi. Zajmiemy się zatem nauczaniem teologów i Magisterium Kościoła dotyczącym teologii stworzenia, zwanej także protologią. Postaramy się także zwrócić uwagę, czy i w jaki sposób prawda ta znajduje wyraz w katechezie. Aby osiągnąć zamierzony cel, przedstawimy najważniejsze prawdy wiary dotyczące stworzenia a następnie zastanowimy się, jakie znaczenia życiowe mają one dla wierzącego. Kolejnym krokiem będzie zaprezentowanie głównych wątków nauczania współczesnego Magisterium Kościoła na temat stworzenia. Filarami tego nauczania będą dokumenty Soboru Watykańskiego II, a także nauczanie Jana Pawła II oraz Benedykta XVI. Przybliżymy następnie najważniejsze elementy nauczania o stworzeniu zawartego w Katechizmie Kościoła Katolickiego. W ostatnim etapie dokonamy krytycznego spojrzenia na nauczanie o stworzeniu na czterech poziomach: Magisterium, nauczania teologów, katechezy oraz na poziomie publicystyki. Poszukiwania oparte zostaną na owocach pracy wielu współczesnych teologów.

\section{STWORZENIE JAKO PRAWDA WIARY}

Najważniejsze dogmaty dotyczące tajemnicy stworzenia można streścić w kilku stwierdzeniach: wszystko, co istnieje poza Bogiem, zostało w całej swojej substancji stworzone przez Boga $\mathrm{z}$ niczego ${ }^{5}$; Bóg stworzył świat

3 Por. Jan Paweł II, Katecheza. Tajemnica stworzenia (8 stycznia 1986), nr 3, http://www.apostol.pl/janpawelii/katechezy/bog-ojciec/tajemnica-stworzenia (dostęp: 22.02.2013).

${ }^{4}$ Tenże, Katecheza. Tajemnica stworzenia, dz. cyt., $\mathrm{nr} 3$.

${ }^{5}$ Por. L. Ott, Fundamentals of Catholic Dogma, Rockford (Illinois) 1974, s. 79. 
z miłości i kierował się przy tym wolnością i mądrością ${ }^{6}$; celem stworzenia jest chwała Boga i szczęście stworzeń ${ }^{7}$; wszystkie Trzy Osoby Boskie były podmiotem stwarzającym i zasadą stworzenia ${ }^{8}$; Bóg stwarzając świat, był absolutnie wolny od jakiegokolwiek przymusu zewnętrznego i wewnętrznego $^{9}$; cały świat stworzony przez Boga jest dobry ${ }^{10}$; świat miał początek $\mathrm{W}$ czasie $^{11}$; Bóg nieustannie podtrzymuje świat $\mathrm{w}$ istnieniu i kieruje nim poprzez Opatrzność ${ }^{12}$.

W Credo nicejsko-konstantynopolitańskim wyrażamy prawdę o Bogu w Trójcy Jedynym jako Stwórcy wszystkiego. Bóg Ojciec jest początkiem i zasadą wszystkiego: „Wierzę w jednego Boga, Ojca wszechmogącego, Stworzyciela nieba i ziemi, wszystkich rzeczy widzialnych i niewidzialnych”. Jezus Chrystus jest Pośrednikiem: „Wierzę w Jednego Pana, Jezusa Chrystusa [...] przez którego wszystko się stało [...] wszystko przez Niego i dla Niego zostało stworzone”. Duch Święty jest dawcą życia: „Wierzę w Ducha Świętego, Pana i Ożywiciela".

Jan Paweł II w jednej z pierwszych katechez o Bogu Ojcu - Stworzycielu przypomina, najważniejsze prawdy wiary dotyczące stworzenia. Papież nauczał, że Bóg stworzył świat sam, bez niczyjej pomocy, z własnej woli, bez żadnego zewnętrznego przymusu ani wewnętrznego zobowiązania. Bóg mógł stworzyć świat, ale mógł go także nie stwarzać. Mógł stworzyć świat taki, jaki jest, albo inny. Świat nie jest odwieczny. Ten świat stworzony przez Boga jest nieustannie podtrzymywany $\mathrm{w}$ istnieniu przez Stwórcę. To podtrzymywanie jest ciągłym stwarzaniem ${ }^{13}$.

W dalszym ciągu tej katechezy Jan Paweł II przypomniał, że Kościół odrzucił poglądy, które podważają taką koncepcję stworzenia, a w związku z tym podważają także chrześcijańską wizję całej rzeczywistości stworzonej. Wśród tych poglądów jest dualizm, materializm, panteizm, emanacjonizm ${ }^{14}$.

W tematyce stworzenia można wyodrębnić jeszcze wiele innych, szczegółowych kwestii, jak chociażby problematykę dotyczącą stworzenia człowieka, interpretacji teorii ewolucji oraz Bożej Opatrzności. Literatura podejmująca te problemy jest bardzo bogata. W ciągu wieków teologia musiała wielokrotnie dokonywać interpretacji wyników badań nauk przyrodniczych w kontekście wyznawanych prawd wiary. Skupimy naszą uwagę na dogmacie o stworzeniu,

\footnotetext{
${ }^{6}$ Por. tamże, s. 80-81.

${ }^{7}$ Por. tamże, s. 81

${ }^{8}$ Por. tamże, s. 82-83.

${ }^{9}$ Por. tamże, s. 83.

${ }^{10}$ Por. tamże, s. 84.

${ }^{11}$ Por. tamże.

12 Por. tamże, s. 87-91.

${ }^{13}$ Por. Jan Paweł II, Katecheza. Bóg powoluje z nicości do istnienia świat i człowieka (29 stycznia 1986), nr 5, http://www.apostol.pl/janpawelii/katechezy/bog-ojciec/b\% C3\%B3g-powo\%C5\%82uje-z-nico\%C5\%9Bci-do-istnienia-\%C5\%9Bwiat-i-cz\%C5\%82owieka

${ }^{14}$ Por. tamże, $\mathrm{nr} 7$.
} (dostęp: 22.02.2013). 
który jest niezmienny. Przyjrzyjmy sie temu, na co Kościół (Magisterium) i teologia zwraca uwagę, wyjaśniając niezmienną prawdę o stworzeniu.

\section{ZNACZENIE PRAWDY O STWORZENIU}

Można zadać sobie pytanie, czy jest sens tak wiele uwagi poświęcać dzisiaj tematyce stworzenia, skoro już właściwie wszystko zostało wyjaśnione. Dogmat się nie zmienia, a więc wydaje się, że teolog nie ma wielkiego pola manewru. Także z punktu widzenia nauk przyrodniczych wydaje się, że najważniejsze zasady, zwłaszcza te dotyczące powstania życia i jego ewolucji, uzyskały rangę dogmatów naukowych, z którymi trudno dzisiaj polemizować. Głębsza analiza problemu pokazuje jednak, że - zwłaszcza w kontekście współczesnej kultury, która próbuje zbudować świat w oderwaniu od prawdy o Bogu i stworzeniu - warto podejmować na nowo kwestię stworzenia.

Problematyka teologiczna nauki o stworzeniu w nauczaniu Kościoła tradycyjnie związana była z trzema kwestiami. Dotyczyło to samego faktu stworzenia, a także sposobu i celu stworzenia. W niniejszym artykule ograniczymy się do samego faktu stworzenia, gdyż wydaje się, że od jego uznania lub nieuznania zależy nasza wizja świata i człowieka.

O wadze i aktualności tego zagadnienia niech świadczy fakt, że zwrócił na nie uwagę Sobór Watykański II. Ojcowie soborowi w Konstytucji duszpasterskiej o Kościele w świecie współczesnym Gaudium et spes zaznaczyli krąg osób, których powinna zainteresować dyskusja na temat stworzenia. Problematyka stworzenia według Soboru nie dotyczy tylko wąskiego grona specjalistów, ale „całej rodziny ludzkiej”. Chodzi o „cały świat, który - jak wierzą chrześcijanie - z miłości Stwórcy powołany [został] do bytu i [jest] zachowywany" ${ }^{\prime \prime}$.

Sobór, analizując sytuację współczesnego świata i wskazując na przyczyny jego kryzysu, zaproponował chrześcijańską wizję rozwiązania problemu. Stwierdził, że także i dzisiaj należy rozumieć świat jako rzeczywistość mającą swój początek w miłości Stwórcy. Ten świat wyzwolony przez Chrystusa, który zwyciężył wszystkie potęgi (także te współczesne, nieliczące się z człowiekiem), przeznaczony jest, zgodnie z wolą Boga, nie do autodestrukcji, ale do samorealizacji ${ }^{16}$. Według ojców soborowych szansę na przezwyciężenie kryzysu współczesnej cywilizacji daje tylko rozumne współdziałanie człowieka ze Stwórcą w Jego dziele. Do tego rozumnego współdziałania powołani są wszyscy ludzie dobrej woli, nawet jeśli nie są chrześcijanami ${ }^{17}$.

\footnotetext{
${ }^{15}$ Sobór Watykański II, Konstytucja duszpasterska o Kościele w świecie współczesnym ,, Gaudium et spes”, nr 2.

${ }^{16}$ Por. tamże.

${ }^{17}$ Por. tamże, nr 67.
} 


\section{NAUCZANIE SOBORU WATYKAŃSKIEGO II}

\section{Stworzenie w Konstytucji Gaudium et spes}

Sobór Watykański II nie podjął systematycznego wykładu na temat teologii stworzenia. Można jednak w kilku miejscach znaleźć sformułowania interesujące dla współczesnego ujęcia tego zagadnienia. Liczne teksty soborowe wyrażają ufność w możliwości twórcze człowieka oraz przekonanie o jego powołaniu do współpracy w przeobrażaniu świata zgodnie z wolą Stwórcy. Profesor Papieskiego Uniwersytetu Świętego Krzyża G. Tanzella-Nitti zauważa, że główne elementy doktryny o stworzeniu znajdują się we wspomnianej wyżej konstytucji Gaudium et spes, dokładnie w punktach 34-39. Konstytucja przedstawia dynamiczną ideę stworzenia. Bóg jest tym, który stwarza, ale w Bożym działaniu człowiek i świat nie są tylko biernymi narzędziami. Rozwój świata, jego ewolucja, to proces otwarty, w którym współdziałaja wzajemnie dwie przyczynowości - Bóg jako pierwsza przyczyna i człowiek jako ten, który został zaproszony do uczestnictwa w stwarzaniu. Sobór stwierdza przy tym autonomię rzeczywistości stworzonych ${ }^{18}$.

Dokument soborowy odsłania na nowo wymiar historiozbawczy stworzenia i jego chrystocentryzm, tak mocno podkreślany $\mathrm{w}$ starożytności chrześcijańskiej ${ }^{19}$. Podkreśla jedność, jaka istnieje pomiędzy początkiem, rozwojem i wypełnieniem się świata stworzonego. Widać wyraźnie jedność pomiędzy protologią, soteriologią i eschatologią ${ }^{20}$. Sobór Watykański II uwolnił współczesną doktrynę o stworzeniu od pewnego schematu myślenia racjonalistycznego i skupił się na przekazie biblijnym analizowanym w perspektywie historiozbawczej.

Sobór zwrócił uwagę na stosunki pomiędzy nauką, techniką, a wiarą. W takich dokumentach, jak Dekret o ekumenizmie (, Unitatis redintegratio”), Dekret o apostolstwie świeckich (,Apostolicam actuositatem”) i Konstytucja duszpasterska o Kościele w świecie współczesnym (,, Gaudium et spes”), ojcowie soborowi zachęcili naukowców z różnych dziedzin nauk empirycznych, humanistycznych i teologicznych do dialogu i współpracy w celu pokonania zła naszych czasów ${ }^{21}$. Sobór zwrócił uwagę na to, że naukowe kosmologie mogą powiedzieć bardzo wiele na temat początków i rozwoju świata, ale nie wszystko. Objawienie i wiara nie zamierzają rywalizować z nauką i filozofią, lecz wychodzą ponad odkrycia tych nauk. Wiara wyjaśnia sens, znaczenie, cele i wartości ostateczne. Sfera poznania religijnego i etycznego jest istotna zarówno dla pojedynczego człowieka, jak i dla całej ludzkości, gdyż odkrywa przed nimi tajemnice świata i człowieka. Świat uka-

\footnotetext{
${ }^{18}$ Stworzenia mają prawa i wartości własne (por. Sobór Watykański II, Konstytucja duszpasterska o Kościele w świecie wspótczesnym ,, Gaudium et spes”, nr 36).

${ }^{19}$ Por. tamże, nr 10.

${ }^{20}$ Por. tamże, $n$ r 38.

${ }^{21}$ Por. G. Tanzella-Nitti, Creazione, w: „Dizionario interdisciplinare Scienza e fede", http://www.disf.org/voci/45.asp (dostęp: 22.02.2013).
} 
zuje się jako miejsce spotkania z nieskończoną Miłością, Dobrem i Mądrością Trzech Osób Bożych. Bóg ukazuje człowiekowi prawdę o jego pochodzeniu i ostatecznym celu, jakim jest komunia miłości z Bogiem żyjącym. W takiej perspektywie historia świata i ludzkości oraz każdej pojedynczej osoby ukazuje się w świetle nieskończonej, kochającej Opatrzności Boga ${ }^{22}$.

Poznanie wiary odkrywa przed człowiekiem nowe horyzonty, dlatego nikt nie ma prawa pozbawiać go możliwości poznania rzeczywistości, do których nie mogą sięgnąć nauki empiryczne. Zasady zdrowego podejścia do kwestii początków świata z perspektywy różnych dziedzin poznania dobrze ilustruje stwierdzenie, że ogromne osiągnięcia dzisiejszej nauki i technologii oraz przewidywalne ich zdobycze $\mathrm{w}$ przyszłości nie zmieniają radykalnie sytuacji, w której oko człowieka widzi to, czego ręka nie jest w stanie dosięgnąć. Należałoby tę prawdę uzupełnić o stwierdzenie, że myśl sięga jeszcze dalej niż to, czego oko nie może zobaczyć, a wiara pozwala patrzeć jeszcze nieskończenie dalej od tego, czego nie może zobaczyć rozum ${ }^{23}$.

\section{Stworzenie w Konstytucji Dei Verbum}

Ważną wskazówkę dla tych, którzy usiłują zgłębić tajemnicę stworzenia, znajdujemy w innym tekście soborowym, a mianowicie w Konstytucji dogmatycznej o objawieniu Bożym Dei Verbum. Według tego dokumentu właściwe zrozumienie tekstu Pisma Świętego jest kluczem do rozwiązania wielu - trzeba zaznaczyć - często pozornych konfliktów pomiędzy naukami empirycznymi a wiarą.

Poszukując prawdy objawionej, należy zwrócić uwagę na gatunek literacki tekstu biblijnego, gdyż każdy gatunek piśmiennictwa przekazuje prawdę w sposób sobie właściwy. Biblijna prawda o stworzeniu ukazana w pierwszych rozdziałach Księgi Rodzaju i innych księgach Pisma Świętego przedstawia w sposób konsekwentny Boga jako Stworzyciela. Bóg jest Stwórcą świata i człowieka ${ }^{24}$. Jest także Zbawicielem. Biblia mówi, że stworzenie nie jest jedyną interwencją Boga. Jest pierwszą interwencją, która zapoczątkowuje całą serię następnych Jego inicjatyw, prowadzących do zbawienia. Wśród nich wielką rolę odgrywają kolejne przymierza, jakie Bóg zawierał z ludźmi, przygotowując ostateczne i wieczne przymierze zawarte w Jezusie Chrystusie.

Konstytucja Dei Verbum przypomina zawartą w Piśmie Świętym prawdę, iż Bóg stworzył świat i człowieka, ale jednocześnie zaznacza, że Biblia nie mówi, w jaki sposób. Odpowiedzi na to pytanie powinny udzielić nauki przyrodnicze pamiętając o tym, że także one mają swoje ograniczenia ${ }^{25}$.

${ }^{22}$ Por. G. Gismondi, Teologia della creazione e cosmologia: prospettivi di dialogo, w: „Convivium Assisiense” V (2003), nr 2, s. 21, http://www.eticaescienza.eu/articoliaggiornati/ teolcreazecosmol.pdf (dostęp: 22.02.2013).

${ }^{23}$ Por. tamże.

${ }^{24}$ Szerzej na ten temat zob. T. Jelonek, Repetytorium biblijne, Kraków 2009.

${ }^{25}$ Por. Sobór Watykański II, Konstytucja dogmatyczna o Objawieniu Bożym „Dei Verbum", nr 12. 


\section{WYPOWIEDZI MAGISTERIUM KOŚCIOŁA NA TEMAT STWORZENIA PO SOBORZE WATYKAŃSKIM II}

\section{Nauczanie Pawła VI o stworzeniu}

Najważniejsze prawdy dotyczące stworzenia przypomniał po zamknięciu Soboru Watykańskiego II papież Paweł VI w Wyznaniu wiary Ludu Bożego: „Wierzymy w jednego Boga, Ojca, Syna i Ducha Świętego, Stwórcę rzeczy widzialnych - do jakich należy świat, w którym żyjemy, oraz niewidzialnych - jakimi są czyste duchy, które nazywamy też aniołami - Stwórcę również duszy duchowej i nieśmiertelnej każdego człowieka" ${ }^{26}$.

Ten sam papież na temat teologii stworzenia wypowiedział się także w roku $1966^{27}$, przemawiając do grupy teologów zaangażowanych w studium nad doktryną o grzechu pierworodnym. Broniąc dogmatu o grzechu pierworodnym, Paweł VI odrzucił poligenizm. Zachęcił przy tym do tego, aby uważnie przeanalizować aktualny stan egzegezy i teologii katolickiej w odniesieniu do tej prawdy wiary, ze szczególnym odniesieniem do rezultatów współczesnych nauk naturalnych, takich jak antropologia i paleontologia ${ }^{28}$.

Paweł VI nie obawiał się konfrontacji prawdy wiary z nauką. Zachęcił do pracy nad tym, aby zdefiniować i przedstawić prawdę o grzechu pierworodnym, tak aby była bardziej współczesna, tzn. uwzględniająca wymogi wiary i rozumu dla człowieka współczesnego. Papież uważał, że dozwolona jest wolność poszukiwań i ocen, jaka jest wymagana w przestrzeni naukowej. Wolność ta nie jest jednak wartością samą dla siebie. Z uwagi na cel Kościoła, jakim jest zbawienie dusz, teolog, egzegeta i naukowiec musi uwzględnić pewne granice, których nie powinien nieroztropnie przekraczać ${ }^{29}$.

\section{Nauczanie Jana Pawła II o stworzeniu}

Nie do przecenienia jest wkład, jaki wniósł w nauczanie o stworzeniu Jan Paweł II. Jego myśl doczekała się wielu opracowań, tak z punktu widzenia nauk przyrodniczych, jak filozofii i teologii. Charakterystyczną cechą głoszonych przez niego prawd jest wierność dotychczasowemu nauczaniu Kościoła i otwartość na nowe odkrycia naukowe ${ }^{30}$. Nauczanie papieża Polaka stanowi swego rodzaju przygotowanie do tego, co o stworzeniu zostało następnie za-

\footnotetext{
${ }^{26}$ Paweł VI, Wyznanie wiary Ludu Bożego. Credo Populi Dei, tłum. J. Królikowski, Kraków 2012.

${ }^{27}$ Por. tenże, Discorso ai partecipanti al simposio sul mistero del peccato originale (11 lipca 1966), http://www.vatican.va/holy_father/paul_vi/speeches/1966/documents/hf_pvi_spe 19660711_peccato-originale_it.html (dostęp: 22.02.2012).

${ }^{28}$ Por. tamże.

${ }^{29}$ Por. tamże.

${ }^{30}$ Podkreślili to m.in. autorzy Oświadczenia katolickich wykładowców filozofii przyrody (20 października 2006) (m.in. ks. prof. M. Heller i abp prof. J. Życiński), http://www.biolog.pl/ article3580.html (dostęp: 22.02.2013).
} 
warte w Katechizmie Kościoła Katolickiego. Warto zwrócić uwagę na przynajmniej niektóre elementy tego papieskiego wykładu o stworzeniu ${ }^{31}$.

W przemówieniu do uczestników kongresu naukowego „Wiara chrześcijańska i teoria ewolucji”, jaki odbył się w Rzymie 26 kwietnia 1985 roku, zatytułowanym Właściwa wiara $w$ stworzenie, właściwe nauczanie ewolucji, Jan Paweł II stwierdził: „Nie kłócą się ze sobą właściwie zrozumiana wiara i właściwie pojęte nauczanie na temat ewolucji; ewolucja bowiem zakłada stworzenie; w świetle ewolucji stworzenie ukazuje się jako wydarzenie, które dokonuje się w czasie - jak creatio continua, w którym Bóg się staje widzialnym dla oczu osób wierzących, jako Stwórca nieba i ziemi” ${ }^{32}$.

Wyjaśniając w katechezach środowych tajemnicę stworzenia, Jan Paweł II przypomniał podstawowe i niezmienne prawdy wiary dotyczące tej tajemnicy. W cyklu katechez o Bogu Ojcu od 8 stycznia 1986 roku do 20 sierpnia 1986 roku papież zajmował się w kolejnych katechezach problematyką stworzenia. Przypomnieliśmy te prawdy na początku naszego artykułu. Interesująca jest katecheza z 16 kwietnia 1986 roku, w której hipoteza ewolucji (jeśli chodzi o ciało człowieka) jest, jak stwierdza papież, możliwa do zaakceptowania i do pogodzenia z prawdą o stworzeniu człowieka przez Boga ${ }^{33}$.

Interesujący jest cały systematyczny wykład, jaki na temat wiary w stworzenie przedstawił Jan Paweł II w swoich katechezach środowych. Przypominając prawdy, w które niezmiennie wierzy Kościól ${ }^{34}$, papież podkreślił, że teologia nie obawia się nauki ${ }^{35}$. Zwrócił także uwagę, że dogmaty dotyczące stworzenia mówią człowiekowi nie tylko o świecie, ale także o Bogu ${ }^{36}$. W czwartej z cyklu katechezie o stworzeniu Jan Paweł II zwrócił uwagę na tajemnicę Trójcy Świętej działającej w stworzeniu: „Stworzenie jest aktem Boga - Trójcy. Świat «stworzony» w Słowie - Synu zostaje wraz z Synem «oddany» Ojcu poprzez ten współistotny obojgu, nie stworzony

${ }^{31}$ Szerzej na ten temat zob. M. Chaberek, Kościót a ewolucja, Warszawa 2012, s. 266-294.

32, ,...] non creano ostacoli una fede rettamente compresa nella creazione o un insegnamento rettamente inteso dell'evoluzione: l'evoluzione infatti presuppone la creazione; la creazione si pone nella luce dell'evoluzione come un avvenimento che si estende nel tempo - come una „creatio continua” - in cui Dio diventa visibile agli occhi del credente come Creatore del Cielo e della terra". (Giovanni Paolo II, Discorso ai partecipanti al Simpozio internazionale se "Fede Cristiana e teoria dell'evoluzione» [26 kwietnia 1985], $\mathrm{nr} 7$, http://www.vatican.va/holy_father/john_paul_ii//speeches/1985/april/documents/hf_jp-ii_spe_ 19850426_studiosi-evoluzione_it.html [dostęp: 22.02.2013]).

${ }^{33}$ Por. Jan Paweł II, Katecheza. Człowiek - obraz Boży - istota duchowo-cielesna (16 kwietnia 1986), http://www.apostol.pl/janpawelii/katechezy/bog-ojciec/cz\%C5\%82owiekobraz-bo\%C5\%BCy-istot\%C4\%85-duchowocielesn\%C4\%85 (dostęp: 22.02.2013).

${ }^{34}$ Por. p. I niniejszego artykułu.

${ }^{35}$ Por. Jan Paweł II, Katecheza. Wiara w Boga, Stworzyciela nieba i ziemi (8 stycznia 1986), nr 2, http://www.apostol.pl/janpawelii/katechezy/bog-ojciec/tajemnica-stworzenia (dostęp: 22.02.2013).

36 Por. tenże, Katecheza. Prawda o stworzeniu należy do objawienia (15 stycznia 1986), nr 1-3, http://www.apostol.pl/janpawelii/katechezy/bog-ojciec/prawda-o-stworzeniunale\%C5\%BCy-do-objawienia (dostęp: 22.02.2013). 
Dar, którym jest Duch Święty. W ten sposób świat zostaje "stworzony» w tej Miłości, jaką jest Duch Ojca i Syna. W czasie, wybranym przez Trójcę jako «początek», ten ogarniony odwieczną Miłością wszechświat zaczyna istnieć. W ten sposób stworzenie świata jest dziełem Miłości. Jest obdarowaniem, czyli darem stworzonym, który ma swoje źródło w Darze nie stworzonym: we wzajemnej Miłości Ojca i Syna. W Trójcy Przenajświętszej”37.

Warto zwrócić uwagę, że stosunkowo wiele miejsca (prawie 1/3 całości wykładu o stworzeniu) papież poświęcił różnym zagadnieniom dotyczącym tajemnicy Bożej Opatrzności. Tajemnicy stworzenia nie sposób zrozumieć, jeśli skupimy się jedynie na samym fakcie stworzenia, jako początku istnienia świata. Dopiero wychodząc od wspomnianej wyżej tajemnicy Trójcy Świętej, możemy zauważyć, że stworzenie nie jest tylko jednorazową interwencją Boga, ale początkiem Jego odwiecznego zamysłu obdarowania stworzenia miłością. Taki kierunek myślenia bliski jest cenionemu przez Jana Pawła II Romano Guardiniemu: „Zdaniem Guardiniego, wiara w Opatrzność może funkcjonować nawet w solidnie naukowo podbudowanej wizji świata, ponieważ związki pojawiające się niekiedy w badaniach fizykalnych, biologicznych, psychologicznych i historycznych mogą przez swą spójność i pewność wywoływać wrażenie, że istnieje jednak jakiś rodzaj «ponadświatowego ładu egzystencji», jakiś sens i moc, które mają źródło w Bogu, na które człowiek zdaje się z religijną ufnością i w które powinien wierzyć" ${ }^{38}$.

Na szczególną uwagę zasługują słowa przesłania Jana Pawła II skierowanego do członków Papieskiej Akademii Nauk zgromadzonych na sesji plenarnej poświęconej powstaniu i pierwotnej ewolucji życia, która odbywała się w dniach 22-26 października 1996 roku. W sesji uczestniczyli naukowcy różnych specjalności, takich jak chemia, biologia, genetyka, astronomia, filozofia i teologia. Wspominano również 60-lecie odnowienia tejże akademii przez papieża Piusa XI. To papieskie przesłanie wprawdzie wykracza poza ramy czasowe przyjęte jako kryterium poszukiwań niniejszego artykułu, jednakże można je traktować jako streszczenie zasadniczych elementów wiary Kościoła w stworzenie. Jan Paweł II wskazuje w nim także konieczne kryteria, jakie należałoby zachować dla prowadzenia owocnego i szczerego dialogu między Kościołem a nauką w tej dziedzinie.

Przypominając dotychczasowe interwencje Magisterium Kościoła, w szczególności stwierdzenia zawarte w encyklice Piusa XII Humani generis oraz w konstytucji Gaudium et spes Soboru Watykańskiego II, a także swoją wypowiedź w związku ze sprawą Galileusza z 31 października 1992 roku, Jan Paweł II stwierdził: „Sformułowanie teorii takiej jak ewolucjonizm wymaga nie tylko przestrzegania zgodności z danymi uzyskanymi z obserwacji, ale także zapożyczenia pewnych pojęć z filozofii przyrody. W rzeczywistości należy mówić nie tyle o teorii, co raczej o teoriach ewolucji. Ich

${ }^{37}$ Tenże, Katecheza. Stworzyciel: Bóg Trójjedyny (5 marca 1986), nr 8, http://www.apostol.pl/ janpawelii/katechezy/bog-ojciec/stworzyciel-b\%C3\%B3g-tr\%CC3\%B3jjedyny (dostęp: 22.02.2013).

${ }^{38} \mathrm{M}$. Kehl, I widziat Bóg, że to jest dobre. Teologia stworzenia, dz. cyt., s. 334. 
wielość wynika $\mathrm{z}$ jednej strony $\mathrm{z}$ różnych sposobów wyjaśniania mechani$\mathrm{zmu}$ ewolucji, a $\mathrm{z}$ drugiej $-\mathrm{z}$ różnych filozofii, które stanowią ich punkt odniesienia. Istnieją mianowicie interpretacje materialistyczne i redukcjonistyczne, a także interpretacje spirytualistyczne. Ich ocena należy do kompetencji filozofii, a dalej-do kompetencji teologii" ${ }^{\prime 39}$.

\section{PRAWDA O STWORZENIU W KATECHIZMIE KOŚCIOEA KATOLICKIEGO}

Dokumentem zamykającym ramy naszych poszukiwań jest Katechizm Kościoła Katolickiego promulgowany przez Jana Pawła II konstytucją Fidei depositum 11 października 1992 roku. Celem Katechizmu, według kard. J. Ratzingera, jest zaprezentowanie współczesnego wykładu niezmiennej doktryny wiary Kościoła. Przedstawiając w sposób systematyczny prawdy wiary, Katechizm stanowi cenne źródło i podstawę dla pogłębionej refleksji teologicznej ${ }^{40}$.

Konstytucja Fidei depositum przypomina, że „Katechizm Kościoła Katolickiego wykłada wiarę Kościoła i naukę katolicką, poświadczone przez Pismo Święte, Tradycję apostolską i Urząd Nauczycielski Kościoła i w ich świetle rozumiane"41. Papież uznał go za ,"pewną normę nauczania wiary”," „symfonię wiary” wiernie i w sposób uporządkowany przedstawiającą nauczanie Pisma Świętego, żywej Tradycji Kościoła i autentycznego Urzędu Nauczycielskiego oraz duchowego dziedzictwa ojców, doktorów i świętych Kościoła $^{43}$. Sam prefekt Kongregacji Nauki Wiary widzi w Katechizmie Kościoła Katolickiego opartą na nauczaniu Soboru Watykańskiego II organiczną wizję całości doktryny wiary katolickiej ${ }^{44}$.

Katechizm Kościoła Katolickiego poświęca wiele uwagi tematyce stworzenia (nr 279-385). Nie podejmując bezpośrednio problematyki stosunku wiary do teorii ewolucji, Katechizm mówi jedynie o świecie stworzonym przez Boga, który jest „«W drodze» do jego ostatecznej doskonałości. To stawanie się dopuszcza w zamyśle Bożym pojawianie się pewnych bytów, a zanikanie innych; dopuszcza obok tego, co najdoskonalsze, także to, co mniej doskonałe; obok budowania natury, również zniszczenia" ${ }^{45}$.

\footnotetext{
${ }^{39}$ Jan Paweł II, Przesłanie do członków Papieskiej Akademii Nauk (22 październiak 1996), nr 4, http://www.jezuici.krakow.pl/nw/doc/jp2ewolucja.htm (dostęp: 15.02.2013).

${ }^{40}$ Por. J. Ratzinger, Attualità dottrinale del Catechismo della Chiesa Cattolica, dopo 10 anni dalla sua pubblicazione, http://www.clerus.org/clerus/dati/2002-10/09-999999/ clita.html (dostęp: 15.02.2013).

${ }^{41}$ Jan Paweł II, Konstytucja ,Fidei depositum”.

${ }^{42}$ Tamże.

${ }^{43}$ Por. tamże.

${ }^{44} \mathrm{~J}$. Ratzinger, Attualità dottrinale del Catechismo della Chiesa Cattolica, dopo 10 anni dalla sua pubblicazione, dz. cyt. (dostęp: 15.02.2013).

${ }^{45}$ Katechizm Kościoła Katolickiego, nr 310.
} 
Katechizm Kościoła Katolickiego dzieli się na cztery części. Chociaż każda $\mathrm{z}$ nich przedstawia inny składnik dziedzictwa wiary, to jednak nie można ich od siebie odrywać. Przekonujemy się o tym, kiedy analizujemy, co Katechizm mówi na temat stworzenia. Wyjaśnia tę prawdę w pierwszej części omawiającej poszczególne artykuły Credo apostolskiego, ale odniesienia do prawdy o stworzeniu znajdujemy także w innych jego rozdziałach. Za przykład niech posłuży nam relacja pomiędzy stworzeniem a zbawieniem. Według Katechizmu sakrament chrztu będący owocem misterium zbawienia dokonanego przez Jezusa Chrystusa jest nowym stworzeniem ${ }^{46}$. W tym sensie należy interpretować śmierć i zmartwychwstanie Jezusa jako interwencję Boga w stworzenie i historię ${ }^{47}$. Katechizm przedstawia także rolę Ducha Świętego w stworzeniu i w całej ekonomii zbawienia, stwierdzając, że Syn i Duch są początkiem bytu i życia każdego stworzenia ${ }^{48}$. Przypomina przy tym, że tajemnicy początku świata nie da się zrozumieć bez odniesienia do prawdy o końcu świata. Stworzenie nie kończy Bożego dzieła, gdyż Bóg chce odnowić wszystko na końcu czasów. W Katechizmie mowa jest więc o nowym stworzeniu w Jezusie Chrystusie. W tym duchu należy rozumieć chrześcijańskie oczekiwanie nowego nieba i nowej ziemi. Jest to oczekiwanie na wypełnienie się rozwoju ziemi i ludzkości, które będzie realizacją zamysłu stworzenia ${ }^{49}$. Wiara $\mathrm{w}$ ostateczne wypełnienie się Bożych planów opiera się na szeroko omawianej w Katechizmie prawdzie o Bożej Opatrzności. Bóg nie zaprzestał nigdy działania, które kieruje świat ku ostatecznej doskonałości ${ }^{50}$.

Interesującą próbę syntetycznego ujęcia wykładu o stworzeniu zawartego w Katechizmie Kościoła Katolickiego znajdujemy w wydanej w roku 1996 książce J. Ratzingera zatytułowanej Gospel, Catechism and Catechesis: Sidelichts on the Catechism of the Catholic Church ${ }^{51}$. Kard. Ratzinger, nawiązując do struktury Katechizmu, stwierdza, że wyjaśnia on Credo apostolskie, które jest wyznaniem wiary w Trójjedynego Boga: Ojca, Syna i Ducha Świętego. W ten sposób pokazana zostaje hierarchia prawd wiary chrześcijańskiej $^{52}$. W wywodzie prefekta Kongregacji Nauki Wiary pojawia się także koncepcja podjęta później w encyklice Deus Caritas est. Wiara chrześcijańska jest wiarą w Boga żywego. Wszystkie inne prawdy koncentrują się i zmierzają do Boga. Wiara nie jest teorią czy systemem prawd, ale wyda-

${ }^{46}$ Por. tamże, nr 612.

${ }^{47}$ Por. tamże, nr 648.

${ }^{48}$ Por. tamże, nr 703.

${ }^{49}$ Por. tamże, nr 1049.

${ }^{50}$ Por. tamże, nr 302.

51 J. Ratzinger, Gospel, Catechism and Catechesis: Sidelichts on the Catechism of the Catholic Church, San Francisco 1997. Jest to angielskie thumaczenie wydanej wcześniej książki Evangelium - Katchese - Katechismus - Streiflichter auf den Katechismus der Katolischen Kirche, Munich 1995.

${ }^{52}$ Por. tenże, Gospel, Catechism and Catechesis: Sidelichts on the Catechism of the Catholic Church, dz. cyt., s. 18. 
rzeniem, spotkaniem z żywym Bogiem, który jest naszym Ojcem, którego Syn przyjął ludzką naturę, który jednoczy nas w Duchu Świętym i który pozostaje jednym i jedynym Bogiem. Takie ujęcie wiary wskazuje na cel nauczania jej prawd. Według kard. Ratzingera wiara, a co za tym idzie także przekaz wiary, musi prowadzić do wzrastania w komunii z Bogiem. W ten sam sposób należy także patrzeć na świat stworzony. Świat odgrywa ważną rolę w spotkaniu człowieka z Bogiem. Widać to szczególnie w strukturze sakramentów, gdzie rzeczywistość znaku zawierająca elementy materialne staje się narzędziem spotkania z Bogiem udzielającym laski-swojego życia ${ }^{53}$.

Ratzinger stwierdza, że dialog z żywym Bogiem odbywa się poprzez świat stworzony. Bóg jest prawdziwym Bogiem jedynie wtedy, kiedy jest Panem wszystkiego. Jest Nim wtedy, kiedy jest Stwórcą. Zaangażowanie Boga nie kończy się jednak na stworzeniu. Boże działanie zmierza do zbawienia. Nauczając o stworzeniu, Katechizm wskazuje na głębszy wymiar tego dzieła. Widzi je w kontekście historii zbawienia, historii zbawczego dialogu Boga z człowiekiem ${ }^{54}$. Stworzenie jest pierwszym elementem tego dialogu.

Kard. Ratzinger wyjaśnia następnie, że stworzenie jest źródłem całego porządku moralnego. Postępowanie moralne, życie moralne pozostaje w ścisłym związku ze światem, który kieruje się $\mathrm{w}$ harmonii ze stworzeniem prawami naturalnymi wszczepionymi w niego przez Boga. Cały świat $i$ jego prawa odzwierciedlają naturę Boga. Człowiek stworzony jest przecież na obraz i podobieństwo Boże. Świat jest obrazem Boga ${ }^{55}$.

Obok tradycyjnych kwestii dotyczących stworzenia w Katechizmie Kościoła Katolickiego poruszone zostają także inne tematy, jak chociażby potwierdzenie centralności tajemnicy Trójcy Świętej dla teologii stworzenia ${ }^{56}$. Katechizm nawiązuje w tym punkcie do tradycji patrystycznej, zwłaszcza do nauczania św. Ireneusza. Ta perspektywa jest czymś nowym w wykładzie prawdy o stworzeniu i pozwala zobaczyć ją w kontekście wszystkich pozostałych prawd wiary. Katechizm wypełnia w ten sposób postulat wielu teologów XX wieku podkreślających centralność tajemnicy trynitarnej jako charakterystykę wiary chrześcijańskiej ${ }^{57}$.

Katechizm Kościoła Katolickiego zwraca uwagę na religijny wymiar prawdy o stworzeniu. Inaczej niż nauki przyrodnicze, które starają się odpowiedzieć na pytanie, jak i kiedy powstał świat, Katechizm, wyjaśniając prawdy wiary, odpowiada na pytanie: dlaczego Bóg stworzył świat ze wszystkim, co istnieje? Bardziej niż na kwestii początku świata, a w nim pochodzenia człowieka, Katechizm koncentruje się na tym, jaki jest cel, ku

\footnotetext{
${ }^{53}$ Por. tamże, s. 29.

${ }^{54}$ Por. tamże.

${ }^{55}$ Por. tamże, s. 16.

${ }^{56}$ Por. Katechizm Kościoła Katolickiego, nr 292.

${ }^{57}$ Zwracał na to uwagę m.in. Henri de Lubac, wyjaśniając Skład apostolski. Zob. tenże, The Christian Faith: An Essay on the Structure of the Apostles' Creed, San Francisco 1986, s. 77.
} 
któremu zmierzamy ${ }^{58}$. Katechizm umieszcza doktrynę o stworzeniu nie w kontekście dyskusji filozoficznych, ale w kontekście historii zbawienia, która zmierza do nowego stworzenia w Jezusie Chrystusie. W takiej wizji stworzenie stanowi fundament całego zbawczego planu Boga i jest początkiem historii zbawienia $^{59}$. Katechizm stwierdza, że Boży zamysł zbawienia ,jest «łaską, która nam dana została [...] przed wiecznymi czasami» (2 Tm 1,9), mającą swoje źródło w miłości trynitarnej. Rozwija się on w dziele stworzenia, w całej historii zbawienia po upadku człowieka, w posłaniu Syna i Ducha Świętego, a przedłużeniem tego posłania jest posłanie Kościoła"60.

$\mathrm{Na}$ uwagę zasługuje także wizja świata oparta na biblijnym przekazie. Świat, który wyszedł z ręki Boga, jest dobry. Boskie początkowe „tak” dla świata nie zostało odwołane nawet po grzechu. Katechizm stwierdza, że „odpowiedzi na to pytanie udziela [...] całość wiary chrześcijańskiej: dobroć stworzenia, dramat grzechu, cierpliwa miłość Boga, wychodząca ciągle naprzeciw człowieka przez Jego przymierza, odkupieńcze wcielenie Jego Syna, dar Ducha Świętego, zgromadzenie Kościoła, moc sakramentów oraz wezwanie do szczęśliwego życia, do którego wszystkie wolne stworzenia są zaproszone, zanim przyjmą jeszcze to wezwanie; lecz mogą także - co jest straszną tajemnicą - z góry je odrzucić" ${ }^{\prime 61}$.

Katechizm podkreśla także porządek i harmonię stworzeń: „Każde stworzenie posiada swoją własną dobroć i doskonałość" "62. Katechizm, opierając się na słynnym tekście św. Franciszka, zachęca do wdzięczności Bogu i odpowiedzialności za powierzony człowiekowi świat. Mamy do czynienia z ważną i delikatną, zwłaszcza z punktu widzenia współczesnego świata, kwestią właściwie rozumianej ekologii. Stworzenie istnieje nie tylko po to, aby zaspokajać potrzeby człowieka, ale także po to aby oddawać chwałę Bogu. Świat przez samo swoje istnienie śpiewa hymn uwielbienia dla Boga ${ }^{63}$. Zadaniem człowieka jest wobec tego szanować prawa, które Stwórca wpisał w swoje dzieło, troszczyć się o nie i chronić je. Nie wolno niszczyć Bożego dzieła $^{64}$. Należy „,czynić wszystko, co możliwe, w celu zmniejszania cierpień ludzkich i braków utrudniających godne prowadzenie życia. Bronić godności stworzenia i nie tylko nie czynić tego, co niszczy środowisko człowieka, ale opiekować się wszystkim, co jest dane człowiekowi dla jego dobra" ${ }^{\text {"65 }}$.

Można oczywiście odnaleźć jeszcze wiele innych interesujących wątków w doktrynie o stworzeniu przedstawionej w Katechizmie Kościoła Ka-

\footnotetext{
${ }^{58}$ Por. Katechizm Kościoła Katolickiego, nr 282. Zob. także: E. Duffy, The Creed in the Catechism: the Life of God for Us, London - New York 2005, s. 19-20.

${ }^{59}$ Por. tamże, s 20.

${ }^{60}$ Katechizm Kościoła Katolickiego, nr 257.

${ }^{61}$ Tamże, nr 309.

${ }^{62}$ Tamże, nr 339.

${ }^{63}$ Por. E. Duffy, The Creed in the Catechism: the Life of God for Us, dz. cyt., s. 26.

${ }^{64}$ Por. Katechizm Kościoła Katolickiego, nr 353.

${ }^{65}$ A.L. Szafrański, Świat i człowiek dziełem Boga, w: Katechizm Kościoła Katolickiego. Wprowadzenie, red. M. Rusecki, E. Pudełko, s. 60.
} 
tolickiego. Dla potrzeb tego artykułu zatrzymamy się jednak w tym miejscu, zwracając uwagę, że Katechizm rozwija tę doktrynę, opierając się na wizji świata zaprezentowanej w konstytucji Gaudium et spes.

Przedstawiliśmy zasadniczo główne idee doktryny o stworzeniu obecne w nauczaniu Magisterium Kościoła w interesującym nas okresie. Nauczanie to jest spójne, jasne i niezmienne. W kolejnym punkcie zwrócimy uwagę na to, czy i w jaki sposób wskazania Magisterium znajdują praktyczne przełożenie na język teologii, katechezy i życia codziennego. Aby uporządkować nasze spostrzeżenia, wyróżnimy cztery poziomy przekazywania prawdy o stworzeniu.

\section{PRAWDA O STWORZENIU W RÓŻNYCH KONTEKSTACH}

\section{Nauczanie Magisterium Kościoła}

Oficjalne nauczanie Kościoła jest w dziedzinie prawdy o stworzeniu jasne i precyzyjne. Przytoczone wyżej przykłady świadczą o tym, że Magisterium jest otwarte na naukowe osiągnięcia w tej dziedzinie. Bierze pod uwagę wyniki odkryć naukowych na temat początków i rozwoju świata i życia na ziemi. W swoich wypowiedziach Urząd Nauczycielski Kościoła zwraca jednak uwagę na konieczność właściwego podejścia, przyjęcia właściwej metodologii, a także na ograniczenia, jakie pojawiają się $\mathrm{w}$ teologii oraz w naukach empirycznych w badaniach nad początkiem świata. Ograniczenia te dotyczą tak teologii, jak i rozumu.

Magisterium, broniąc niezmiennych dogmatów, zachęca do dialogu naukowców z różnych dziedzin w imię zasady, która mówi, że wiara szuka zrozumienia, a rozum szuka wiary, nie stawiając Bogu ograniczeń. Prawda rozumu i prawda wiary wypływają z tego samego źródła, którym jest sam Bóg, nie ma więc konfliktu pomiędzy wiarą a rozumem, pomiędzy wiarą a odkryciami nauk przyrodniczych.

\section{Nauczanie teologów}

W wykładzie prawdy o stworzeniu po Soborze Watykańskim II można zauważyć próbę opracowania jakiegoś nowego schematu, jakiegoś nowego klucza, umożliwiający włączenie doktryny o stworzeniu w kontekst pozostałych prawd wiary. Teologia starała się znaleźć taki klucz, który pozwoliłby przedstawić $\mathrm{w}$ sposób systematyczny teologię stworzenia. W omawianym przez nas okresie pojawiają się takie idee. Teologia stworzenia prezentowana jest w kontekście teologii trynitarnej. Podkreśla się kontekst historiozbawczy, personalistyczny i chrystologiczny doktryny o stworzeniu.

Przed Soborem Watykańskim II traktat o Bogu Stwórcy umiejscowiony był najczęściej w obrębie albo na końcu traktatu o Bogu Jedynym. Wiele miejsca w wykładzie zajmowała analiza pojęć, takich jak natura aktu stwórczego, przymioty aktu stwórczego itp., analiza poszczególnych dzieł 
stworzenia - świat, byty duchowe i człowiek. Wykład wychodził od analizy pojęć z punktu widzenia filozofii i metafizyki, następnie przechodzono do nauczania Magisterium, które znajdowało potwierdzenie w nauczaniu ojców Kościoła i w Piśmie Świętym.

Po Soborze Watykańskim II w wykładni nauki o stworzeniu zasadnicze znaczenie, jako punkt wyjścia, zaczyna przejmować Pismo Święte. Wychodząc od analizy danych objawienia, poprzez definicje Magisterium teolodzy staraja się dojść do wyjaśnienia szczegółowych kwestii. Coraz częściej pojawia się konieczność konfrontowania prawd wiary z odkryciami nauk przyrodniczych.

Jako ilustracja może posłużyć przykład wielkiego polskiego teologa, ks. Wincentego Granata. Jeszcze przed Soborem Watykańskim II w publikacjach W. Granata można zauważyć klasyczne podejście. Traktat o stworzeniu umieszczony jest po traktacie De Deo Uno. Klasyczny jest również wykład doktryny stworzenia, chociaż obfituje w naukowe fakty dotyczące powstania świata ${ }^{66}$. Także w syntezie dogmatyki, czyli skrócie wszystkich wcześniejszych tomów, obecny jest jeszcze klasyczny wykład ${ }^{67}$. W wydanej w roku 1972 syntezie zatytułowanej Ku Bogu i człowiekowi w Chrystusie widać już nowy klucz. W. Granat szuka jakiejś jednoczącej idei. Jest nią człowiek w jego środowisku życia. Świat postrzegany jest jako ośrodek życia i działania człowieka. Kontekst historiozbawczy jest zarysowany, chociaż jeszcze wciąż jakby nieśmiało, ale pojawia się już np. klucz trynitarny ${ }^{68}$.

\section{Nauczanie katechetyczne}

Dość ostrożnie na tematy dotyczące stworzenia wypowiada się katecheza. Warto zauważyć, że na poszczególnych poziomach kształcenia (w omawianym okresie funkcjonuje jeszcze ośmioklasowa szkoła podstawowa i trzy-, cztero- lub pięcioletnie szkoły ponadpodstawowe) stworzenie i relacja wiara - nauka nie stanowi głównego tematu katechezy. Badając przykładowo klasyczne i wzorcowe w tym czasie podręczniki opracowane w zespole pod kierownictwem ks. Charytańskiego ${ }^{69}$, zauważamy zaledwie jedną, dwie lub trzy jednostki katechetyczne poświęcone tematyce stworzenia na poszczególnych poziomach (nie mówimy o klasach). Tematyka ta pojawia się na przykład w tzw. historii biblijnej. W katechezie dla szkoły średniej mamy także tylko jedną lub dwie jednostki lekcyjne. Najczęściej doktryna stworzenia poruszana jest $\mathrm{w}$ związku $\mathrm{z}$ omawianiem biblijnego opisu stworzenia. Innym kontekstem, w którym możemy spotkać naukę o stworzeniu, jest nauka metod czytania tekstu biblijnego. Można oczywiście zapytać, czy

\footnotetext{
${ }^{66}$ Por. W. Granat, Bóg Jeden w Trójcy Osób, Lublin 1962.

${ }^{67}$ Por. tenże, Dogmatyka katolicka. Synteza, Lublin 1967.

${ }^{68}$ Por. tenże, Ku czlowiekowi i Bogu w Chrystusie. Zarys dogmatyki katolickiej, t. 1, Lublin 1972.

${ }^{69}$ Bóg z nami - klasy I-IV, Katechizm religii katolickiej - klasy V-VIII, Spotkania z Chrystusem - szkoła średnia.
} 
nie mamy tutaj do czynienia $\mathrm{z}$ pewną obawą przed trudnymi pytaniami na tym poziomie nauczania. Generalnie możemy zauważyć pewien niedobór skutecznej i wyczerpującej odpowiedzi na te pytania, które rodzą się u dzieci i młodzieży w wyniku przekazywanej w szklonych programach na lekcjach biologii informacji o teorii ewolucji.

\section{Publicystyka}

$\mathrm{Na}$ tym poziomie mamy do czynienia z rozpaloną polemiką. Po dwóch stronach barykady możemy spotkać stanowiska fundamentalistyczne. Konflikt często jest definiowany jako spór pomiędzy kreacjonizmem a ewolucjonizmem. Zauważyć należy przy okazji tego sporu, że po stronie kreacjonistów umieszcza się - często nie pytając ich o zdanie - wszystkich tzw. ortodoksyjnych wierzących. Po drugiej stronie umieszczani są wszyscy uznający tzw. „naukowy pogląd” na świat. Podział wydaje się jasny. Z jednej strony mamy ciemnogród, a z drugiej oświeconych i uczonych. Uczestnicy tego sporu najczęściej w ogóle nie pytają się poważnie o to, co tak naprawdę na temat stworzenia mówi nauka, ani o to, co mówi wiara, czyli dogmat. Nie interesuje ich, co jest dogmatem, a co teorią stworzoną przez teologów. Nie zwracają uwagi na to, co jest naukowo potwierdzonym faktem, a co hipotezą, i na ile ta hipoteza jest naukowa.

Wydaje się, że uczestnicy tego sporu, który znajduje odzwierciedlenie w prasie, radiu, w telewizji i w Internecie, w ogóle nie są zainteresowani dążeniem do poznania prawdy. Nie interesuje ich ani prawda naukowa, ani prawda wiary na temat pochodzenia świata. Przystępują do dyskusji z ustalonymi z góry teoriami zbudowanymi raczej na ideologii niż na naukowych twierdzeniach. Wydaje się wobec tego bezcelowe z punktu widzenia naukowego zajmowanie się takimi sporami. Obserwując toczącą się dyskusję z boku, można także zapytać, czy chodzi rzeczywiście o kwestię „Kościół a ewolucja, teologia a ewolucja". W tej dziedzinie jednak ze strony Kościoła konfliktu nie ma. Może wobec tego chodzi raczej o kwestię „Kościół a teorie ewolucji”? W tym przypadku, rzeczywiście, może dochodzić do konfliktu.

\section{PODSUMOWANIE}

Zamiast podsumowania można na koniec zapytać: co takiego stało się w dziedzinie nauczania doktryny o stworzeniu w tych granicznych punktach - od zakończenia Soboru Watykańskiego II do opublikowania Katechizmu Kościoła Katolickiego? Można także zapytać: co takiego się stało, że uważamy te wydarzenia za punkty graniczne? Przecież jeśli chodzi o tematy, które wstrząsnęly ideą stworzenia i zmusiły Magisterium Kościoła do zajęcia doktrynalnego stanowiska, to istnieją bardzo intersujące problemy, które wymagałyby większego zainteresowania, jak chociażby kwestie dotyczące pochodzenia człowieka i inne prezentowane w encyklice Piusa XII Humani 
generis, czy teoria Wielkiego Wybuchu i jej interpretacja w świetle doktryny chrześcijańskiej. Te tematy - zapewne bardzo interesujące - wymagają osobnego opracowania. Nie umniejszając znaczenia wspomnianych wyżej kwestii, możemy zauważyć, że w nauczaniu o stworzeniu w zakreślonych na wstępie ramach czasowych zaszła jednak interesująca zmiana. Chodzi o zmianę pewnej perspektywy - teologicznej i naukowej - w ujmowaniu i wyjaśnianiu niezmiennego dogmatu. Nastąpiło wyraźne zbliżenie kreatologii do trynitologii. Widać również wyraźne otwarcie wykładu o stworzeniu na nauki przyrodnicze. Istotna jest także perspektywa personalistyczna pozwalająca widzieć stworzenie nie jako bezosobowy akt, ale jako działanie kochającego, osobowego Boga. Oceniając nauczanie doktryny o stworzeniu $\mathrm{z}$ właściwej perspektywy, możemy zauważyć, że teologia nie boi się podkreślania autonomii rzeczy i świata stworzonego, ale autonomię tę należy widzieć we właściwej perspektywie wolności. Nie chodzi o uwolnienie się od panowania Boga, od zależności od Niego. Nie chodzi o „wolność od Boga”, ale o wolność „ku Bogu". Prawa fizyki, biologii, prawa przyrody nie odrywają świata od Stwórcy, ale właśnie przybliżają ku Niemu i pomagają człowiekowi w odkrywaniu zamysłu Bożego, zamysłu miłości.

Bóg jest na tyle potężny, że nie boi się wyposażyć świat w wewnętrzne prawa i pozwala mu się rozwijać. Autonomia rzeczy doczesnych, o której mówi konstytucja Gaudium et spes, pokazuje, że Bóg ma zaufanie do swego stworzenia. Jeśli tylko człowiek nie próbuje ingerować w prawa przyrody $\mathrm{i}$ „ulepszać” natury po swojemu, to wszystko funkcjonuje właściwie. Tylko człowiek, który usiłuje zająć miejsce Boga, ignoruje prawdę o stworzeniu. Przyjęcie właściwej perspektywy pozwala zobaczyć Boga w centrum świata i człowieka w centrum zamysłu Bożego. Ten zamysł nie jest jakąś abstrakcyjną ideą, ale myślą Osoby, która kocha. 